\title{
Stainless Steel Recycle FY94 Progress Report
}

by

K. J. Imrich

Westinghouse Savannah River Company

Savannah River Site

Aiken, South Carolina 29808

DOE Contract No. DE-AC09-89SR18035

This paper was prepared in connection with work done under the above contract number with the U. S.

Department of Energy. By acceptance of this paper, the publisher and/or recipient acknowledges the U. S. Government's right to retain a nonexclusive, royalty-free license in and to any copyright covering this paper, along with the right to reproduce and to authorize others to reproduce all or part of the copyrighted paper. 


\section{DISCLAIMER}

Portions of this document may be illegible in electronic image products. Images are produced from the best available original document. 


\section{DISCLAIMER}

This report was prepared as an account of work sponsored by an agency of the United States Government. Neither the United States Government nor any agency thereof, nor any of their employees, makes any warranty, express or implied, or assumes any legal liability or responsibility for the accuracy, completeness, or usefulness of any information, apparatus, product, or process disclosed, or represents that its use would not infringe privately owned rights. Reference herein to any specific commercial product, process, or service by trade name, trademark, manufacturer, or otherwise does not necessarily constitute or imply its endorsement, recommendation, or favoring by the United States Government or any agency thereof. The views and opinions of authors expressed herein do not necessarily state or reflect those of the United States Government or any agency thereof.

This report has been reproduced directly from the best available copy.

Available to DOE and DOE contractors from the Office of Scientific and Technical Information, P.O. Box 62, Oak Ridge, TN 37831; prices available from (615) 576-8401.

Available to the public from the National Technical Information Service, U.S. Department of Commerce; 5285 Port Royal Road, Springfield, VA 22161. 
WSRC-TR-94-0527 (U)

\title{
STAINLESS STEEL RECYCLE FY94 PROGRESS $\operatorname{REPORT}(U)$
}

\author{
Principal Investigator \\ K. J. Imrich \\ Program Participants \\ D. R. Leader \\ M. R. Louthan Jr. \\ N. C. Iyer \\ E. A. Clark \\ R. R. Lathrop \\ T. L. Reown \\ K. R. Hicks
}

Savannah River Technology Center

Applied Science \& Technology Department

Materials Technology Section

Publication Date: October 28, 1994

Westinghouse Savannah River Company

Savannah River Site Aiken, SC 29808

This document was prepared in connection with work done under Contract No. DE-AC09-89SR18035 with the U. S. Department of Energy. By acceptance of this document, the publisher and/or recipient acknowledges the U. S. Government's right to retain a nonexclusive, royalty-free license in and to any copyright covering this document, along with the right to reproduce and authorize others to reproduce all or part of the copyrighted material. 


\section{CONTENTS}

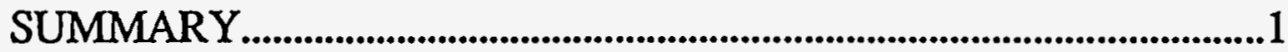

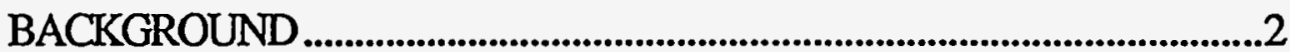

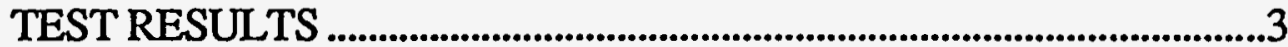

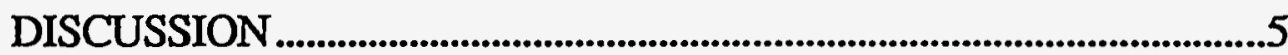

TRITIUM DECONTAMINATION.........................................................5

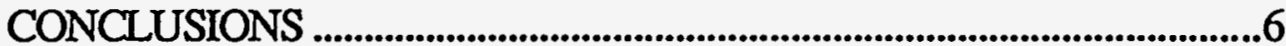

\section{LIST OF FIGURES}

Photograph of $\mathbf{R}$ Reactor Process Water Pipe

Sectioned for Furnace Charging........................................................7

Photograph of Inductotherm Air Induction Furnace...............8

X-Ray Fluorescence Analysis of First Clean Melt.......................9

Photograph of Ingot from the Second Clean Melt......................10

Photomicrograph Showing As-Cast Structure of Ingot from Second Clean Melt

Photomicrograph Showing Directionally Solidified

Microstructure of Ingot from the Third Clean Melt.................12

Photomicrograph of Ingot from the Third Clean

Melt in the As-Rolled Condition

Photomicrograph of Ingot from the Third Clean

Melt in the As-Rolled and Heat Treated Condition....................1 4

Photomicrograph of Ingot form the Second

Contaminated Melt in the As-Cast Condition...............................15 
Subject Describers

Stainless Steels

Recycling

Contamination

Decontamination

Melting

WSRC-TR-94-0527

\section{STAINLESS STEEL RECYCLE FY94 PROGRESS REPORT (U)}

\section{Summary}

The findings presented in this investigation lead to the following conclusions:

1. Recycle of $18 \mathrm{wt} \% \mathrm{Cr}-8 \mathrm{wt} \% \mathrm{Ni}$ alloy can be achieved by melting Type 304 stainless steel in a air vacuum induction furnace.

2. Limited melt decontamination of the contaminated stainless steel was achieved. Surface contamination was removed by standard decontamination techniques.

3. Carbon uptake in the as-cast ingots resulted from the graphite susceptor used in this experiment and is unavoidable with this furnace configuration. A new furnace optimized for melting stainless steel has been installed and is currently being tested for use in this program.

4. The decontamination efficiency through melt processing for typical batches of contaminated stainless steels needs to be fully established.

\section{Background}

The Materials Technology Section (MTS) of the Savannah River Technology Center (SRTC) is providing technical, facility and personnel support for the Office of Development funded Technical Task Plan SR1-4-20-03, Stainless Steel Beneficial Reuse Demonstration. This program was established to demonstrate the practicality of recycling previously contaminated stainless steel components such as reactor heat exchanger heads, process water piping and slug buckets into 208 liters (55 gallon) drums and 2.8 cubic meter (100 $\left.\mathrm{ft}^{3}\right)$ storage boxes. Radioactively contaminated stainless steel scrap will be sent to several industrial partners where it will be melted, decontaminated/cast into ingots, rolled into plate and sheet and fabricated into the drums and boxes. 
W. L. Boettinger

October 28, 1994

Page 2 of 15

WSRC-TR-94-0527

As part of this recycle initiative, MTS was requested to demonstrate that radioactively contaminated Type 304L stainless steel could be remelted and cast to meet the applicable ASTM specification for fabrication of drums and boxes. In addition, MTS was requested to develop the technical basis of melt decontamination and establish practicality of using this approach for value added products.

In preparation for contaminated melts, a National Emission Standard for Hazardous Air Pollutants (NESHAP) exemption was obtained and included modeling of anticipated environmental releases. This model was based on a conservative source term consisting of Co-60, Pu-238 and tritium. In depth reviews by representatives from Health Physics (HP), Industrial Hygiene (IH) and Occupational Safety and Health Administration (OSHA). were required prior to startup of the decontamination/casting/fabrication process. In addition, numerous melts with non-contaminated feed stock were made to test equipment, verify the process and characterize the cast material prior to melting contaminated stainless steel. Type 304L stainless steel scrap for the non-contaminated melts was supplied by the SRTC machine shop. Process water pipe from R-Area was used as feed material for all contaminated melts (Figure 1). Final sizing of the materials was performed with a plasma torch in a tritium hood. Surface contamination was removed from the feed stock through a series of nitric acid and water rinses. Testing and validation of the melting process was performed in the SRTC Fabrication Lab in a $45 \mathrm{~kg}$ (100 lb) capacity, $3000 \mathrm{~Hz}$ induction melter (Figure 2). The induction furnace was designed to use graphite crucibles (susceptors), thus the initial melts were made in graphite crucibles. However, during later melts aluminum oxide or zirconium oxide crucibles were placed inside the graphite susceptors to minimize carbon uptake. Charges consisted of approximately $9 \mathrm{~kg}(20 \mathrm{lbs})$ of scrap metal and several pounds of borosilicate frit. The frit, which forms a slag over the molten metal, was used to minimize oxidation of the molten metal and trapped radionuclides. The charged crucible was placed in the graphite crucible inside the furnace and heated to approximately $1500^{\circ} \mathrm{C}$. Melt and pour cycle times ranged from 2 to 4 hours. Melt temperatures were monitored with a $\mathrm{K}$ type thermocouple (up to $\sim 1200^{\circ} \mathrm{C}$ ) and an optical pyrometer. Off-gas monitoring for tritium was performed using constant air monitors located near the furnace. Initially the molten stainless steel was poured directly into either graphite crucibles or preheated carbon steel molds; however, later heats were cast into sand molds. The casting sand mixture consisted of a bentonite binder $(9 w t \%)$ and water $(\sim 4 w t \%)$ and sand (remainder). Castings from contaminated melts were surveyed by HP for 
W. L. Boettinger

October 28, 1994

Page 3 of 15

WSRC-TR-94-0527

residual surface contamination and sectioned in the Hot Machine Shop to obtain metallurgical samples.

\section{Test Results}

The first clean heat of stainless steel was melted in a graphite crucible with no frit and was poured into a graphite crucible. Elemental analysis using a Scanning Electron Microscope with X-Ray Fluorescence (XRF) indicated the material consisted of $18 \mathrm{wt} \% \mathrm{Cr}$ and $7 \mathrm{wt} \% \mathrm{Ni}$. Carbon analysis using a LECO Carbon Analyzer revealed carbon contents in excess of $3.5 \mathrm{wt} \%$. Hardness values ranged from 42 to 46 on the Rockwell $C$ scale and were consistent with the carbon analysis.

A second clean melt was made; however, an alumina crucible and borosilicate frit were used to minimize carbon uptake. This method was successful and produced an ingot with a nickel and chromium content consistent with a Type 304 stainless steel (Figure 3 and 4). Optical metallography revealed a microstructure typical of a cast stainless steel (Figure 5). Depletion of the chromium and nickel were observed in the near surface region of the ingot to depths of approximately $1 \mathrm{~mm}(0.039 \mathrm{in})$. This is indicative of high temperature oxidation which occurred after the metal was cast. Replacement of the graphite crucibles significantly decreased the carbon uptake but carbon content was still higher than expected. Values ranged from $0.32 \mathrm{wt} \%$ in the core to $0.56 \mathrm{wt} \%$ around the outer surface. Carbon uptake is attributed to the use of the graphite mold. Hardness readings taken on a cross-section of the ingot are consistent with the carbon analyses and revealed that the hardness increased with distance from the core (70 to 90 Rockwell B).

The third clean heat was performed in an alumina crucible using a borosilicate frit and was poured into a steel mold which was coated with an alumina mold wash and preheated to $500^{\circ} \mathrm{C}$. The steel mold quenched the molten steel which resulted in directionally solidified microstructure and segregation of the carbon (Figure 6). Carbon contents of the casting ranged from $1.0 \mathrm{wt} \%$ at the top to $0.05 \mathrm{wt} \%$ near the bottom where cooling rates were faster. A $3 \mathrm{~cm}$ square section was cut from the lower (low carbon) portion of the casting and cold rolled. Six passes were used to produce a $80 \%$ reduction in thickness which resulted a characteristic elongated microstructure (Figure 7). Edges of the sample were ground several times to remove small cracks that had formed during the rolling process. The rolled specimen was then heat treated to $1000^{\circ} \mathrm{C}$ for two hours and air cooled to produce a microstructure typical of recrystallized, wrought austenitic stainless steel 
W. L. Boettinger

October 28, 1994

Page 4 of 15

WSRC-TR-94-0527

(Figure 8). Numerous small uniformly distributed inclusions were visible throughout the cross-section.

Contaminated stainless steel from R-reactor was sized and partially decontaminated using nitric and water rinses. Surface contamination levels were reduced from $20,000 \mathrm{~d} / \mathrm{m}$ alpha and $100,000 \mathrm{~d} / \mathrm{m}$ beta/gamma to 4,000 $\mathrm{d} / \mathrm{m}$ and $20,000 \mathrm{~d} / \mathrm{m}$ respectively. Smearable levels of tritium were also reduced from $2,000 \mathrm{~d} / \mathrm{m}$ to $1,700 \mathrm{~d} / \mathrm{m}$ after decontamination. Standard $\mathrm{HP}$ measurement techniques were used for these evaluations. Following melting and pouring all radiation levels were below background levels. Drilling of this casting was extremely difficult and was discontinued. Due to the high hardness of this ingot, which was attributed to excessive carbon, no metallurgical specimens were sectioned.

A second contaminated heat was prepared using the same decontaminated RReactor process water piping. Melting was performed in an alumina crucible with borosilicate frit. This charge was melted at approximately $1500^{\circ} \mathrm{C}$ and cast in a sand mold. An ingot approximately $14 \mathrm{~cm}$ in diameter by $18 \mathrm{~cm}$ tall was poured and allowed to slow cool (Figure 9). Surface contamination above background levels was detected using a portable count rate meter. Drillings from the ingot and slag were submitted for radionuclide characterization. Results from the drillings showed the presence of $\mathrm{Co}-60$ and $\mathrm{Sb}-125$. No other gamma-emitters were detected. The Sb-125/Co-60 ratio was about $8 \%$, and is similar to the L-Area material which will be shipped to various off-site recyclers. Co- 60 activity in the metal was $125 \mathrm{pCi} / \mathrm{g}$ while slag sampled from around the ingot indicated $215 \mathrm{pCi} / \mathrm{g}$. Further radionuclide characterization of the slag and ingot is being pursued. No tritium was detected in the off-gas or in the vicinity of the furnace. Microstructural analysis of a region machined from the core of the casting revealed a structure with random distribution of graphite flakes and small nodules. The as-cast structure did not reveal any preferred orientation and is attributed to the uniform slow cooling of the casting in the insulated sand mold.

\section{Discussion}

Laboratory scale experiments were performed that successfully remelted and cast an austenitic material containing the specified chromium and nickel content to be considered a Type 304 stainless steel. However, carbon uptake has proven difficult to avoid and was observed in all of the melts, some in excess of $1.0 \mathrm{wt} \%$. The carbon rich environment has been attributed to the close proximity of the graphite susceptor to the melt. The use of the 
W. L. Boettinger

October 28, 1994

Page 5 of 15

WSRC-TR-94-0527

borosilicate frit has reduced the uptake; however, $\mathrm{L}$ grades (i.e., less than 0.03 wt\% carbon) will be virtually impossible to produce with this furnace configuration. Therefore, a new $23 \mathrm{~kg}(50 \mathrm{lb})$ capacity induction furnace designed for melting stainless steel, has recently been installed and is being tested. This furnace uses a coil that is specifically designed for melting stainless steel, thus a graphite susceptor is not required. This will eliminate the carbon rich environment currently experienced and allow for the production of Types 304 and 304L stainless steel with adequate mechanical properties. In addition to the new air induction furnace, a new Retech vacuum induction furnace has been acquired independent of this program. This furnace will allow further environmental control and off-gas measurement for tritium.

Laboratory scale experiments have demonstrated that melt decontamination of previously contaminated feed stock can be achieved in an air induction furnace with a borosilicate frit. An increase in Co-60 activity was observed in the slag indicating that there was transfer of radionuclides from the molten metal to the slag. However, the hypothesis that some metal or metal oxides may have cross contaminated the slag is currently being investigated. Further contaminated melts and extensive radionuclide characterization will be required to assess the degree of decontamination.

\section{Tritium Decontamination}

A significant fraction of the DOE owned, radiologically contaminated austenitic stainless steel available for use in the recycle program is contaminated with tritium. This hydrogen isotope may be very mobile, even in stainless steel which has been cooled to room temperature. The migration of tritium in metals and alloys has been studied at the Savannah River Site for decades. These studies have led to an excellent understanding of tritium uptake in, and release from, austenitic stainless steel. However, little attention has been given to tritium release and/or retention during a meltcasting process. Successful recycle of the tritium contaminated components will require assurance of tritium removal during the decontamination, melting and casting processes. Current efforts to develop this assurance include developing, through review of the literature on hydrogen in metals, the understanding of tritium behavior in molten stainless steel and at temperatures above $1000^{\circ} \mathrm{C}$. This understanding will be coupled with the extensive data based on tritium behavior in austenitic stainless steels at lower temperatures to model the anticipated degree of tritium removal during the recycle process. Preliminary analysis suggests that the bulk of the tritium 
W. L. Boettinger

October 28, 1994

Page 6 of 15

WSRC-TR-94-0527

contamination will be associated with the exposed surfaces and will be removed as the metal is heated to the melting temperature. The tritium model will be further developed and experimentally evaluated during the laboratory melt-casting processes. This task will be completed in FY95.

\section{Conclusion}

The findings presented in this investigation lead to the following conclusions:

1. Recycle of $18 \mathrm{wt} \% \mathrm{Cr}-8 \mathrm{wt} \% \mathrm{Ni}$ alloy can be achieved by melting Type 304 stainless steel in a air vacuum induction furnace.

2. Limited melt decontamination of the contaminated stainless steel was achieved. Surface contamination was removed by standard decontamination techniques.

3. Carbon uptake in the as-cast ingots resulted from the graphite susceptor used in this experiment and is unavoidable with this furnace configuration. A new furnace optimized for melting stainless steel has been installed and is currently being tested for use in this program.

4. The decontamination efficiency through melt processing for typical batches of contaminated stainless steels needs to be fully established. 
W. L. Boettinger

October 28, 1994

Page 7 of 15

WSRC-TR-94-0527

\section{FIGURE 1}

Photograph of R Reactor Process Water Pipe Sectioned for Furnace Charging

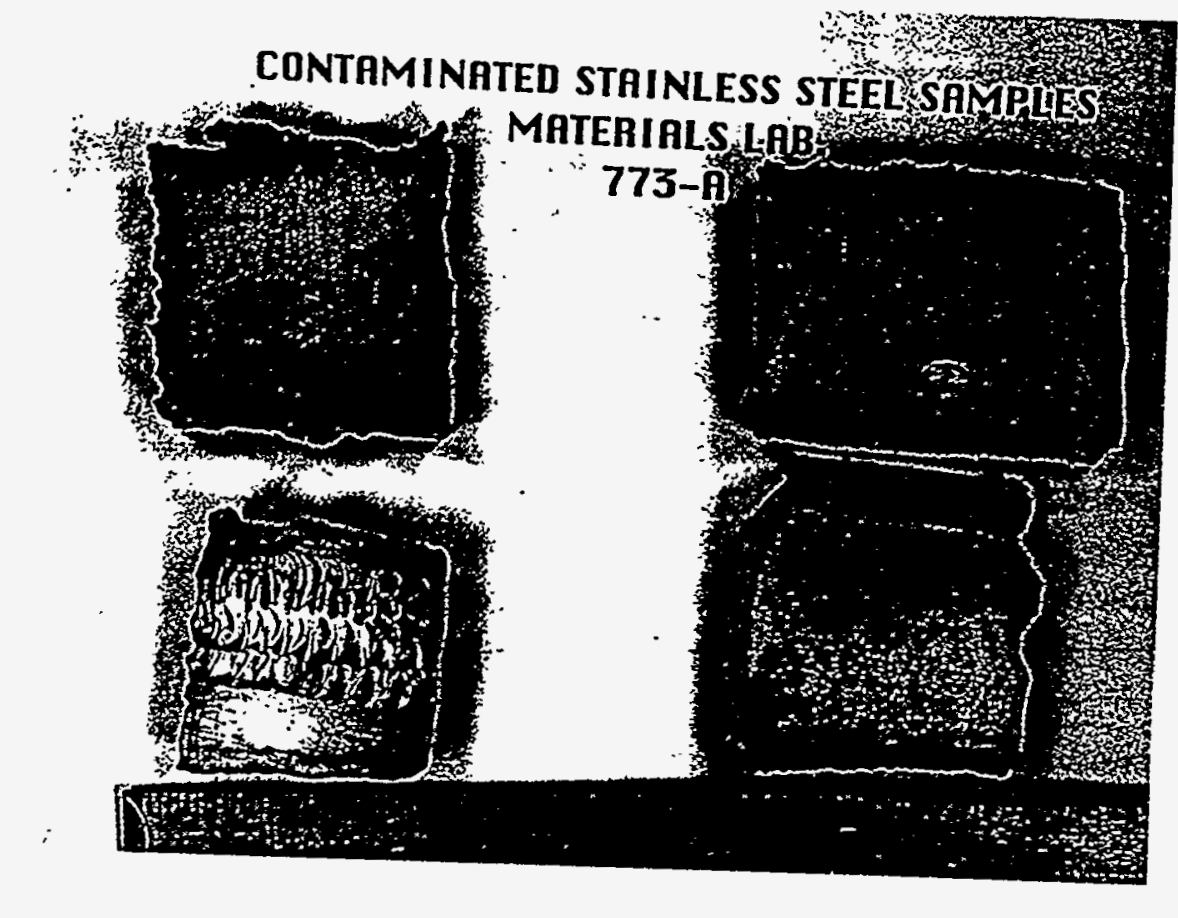


W. L. Boettinger

October 28, 1994

Page 8 of 15

WSRC-TR-94-0527

\section{FIGURE 2}

Photograph of Inductotherm Air Induction Furnace

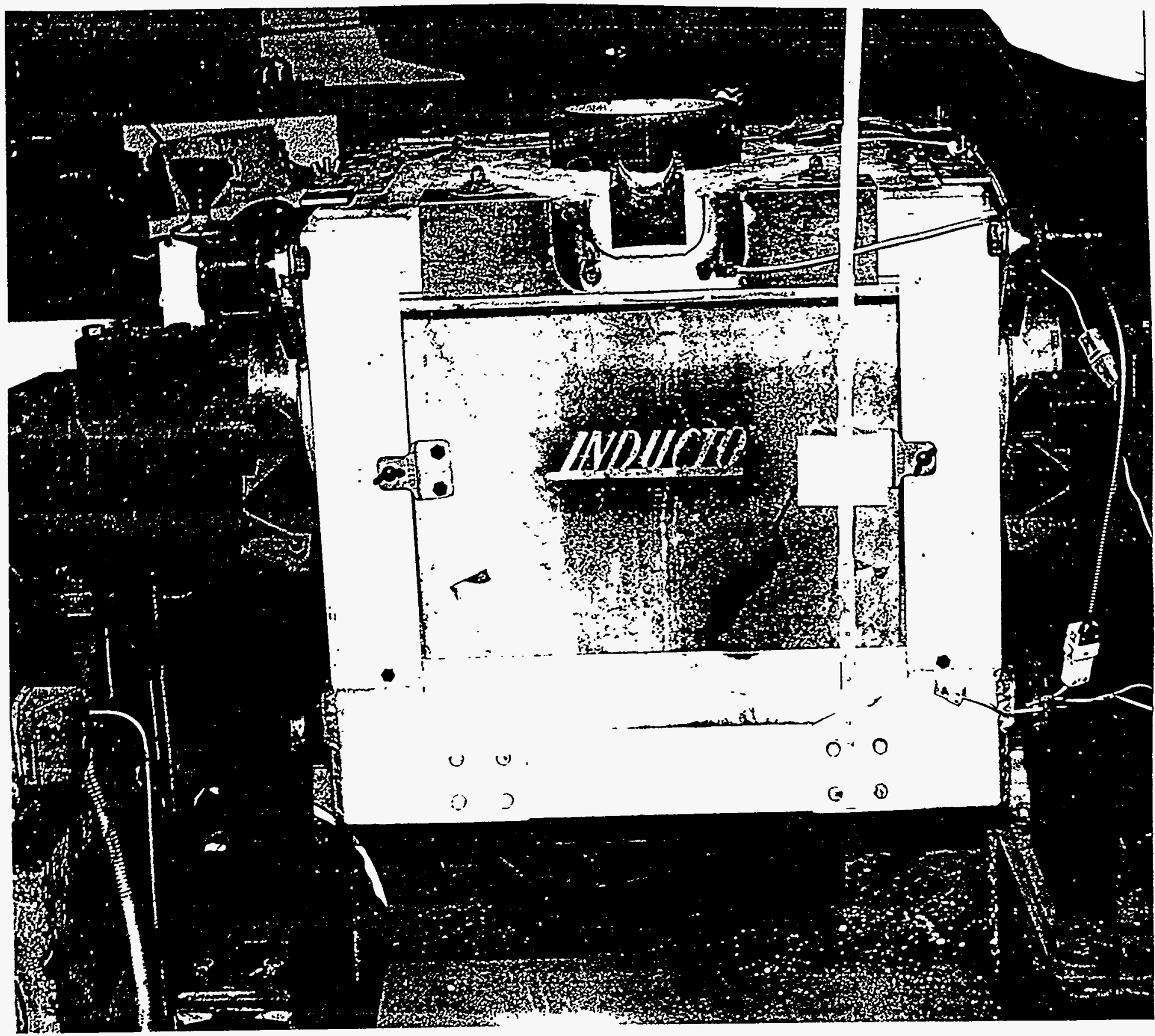


W. L. Boettinger

October 28, 1994

Page 9 of 15

WSRC-TR-94-0527

\section{FIGURE 3}

\section{X-Ray Fluorescence Analysis of First Clean Melt}

2-Dec-1993 15:08:45

Execution time $=13$ seconds

Stainless Steel Recycling First Heat High Corbonpreset =

Vert $=1894$ counts Disp $=1$

1 Comp $=3$ Elapsed=

ED SECS

ELEMENT WEIGHT ATOMIC PRECISION

\& LINE PERCENT PERCENT* 3 SIGMA

K-RATIO** ITER

$S$ i $K A$

0.54

1.07

0. 24

0.0630

Cr KA

18.51

19.57

0.79

घ. 2129

$\mathrm{Mn} \mathrm{KA}$

1.84

1.84

0. 50

घ. 0185

$\mathrm{Fe} \mathrm{KA}$

71.83

70.71

1. 78

$\mathrm{Ni} \mathrm{KA}$

7.28

6.82

0.78

0. 7011

घ. ถEE 4

TOTAL 100.00

*NOTE: ATOMIC PERCENT is nornalized to 100 **NOTE: K-RATIO = K-RATIO $\times$ R Quaritext>where $R=$ referenee(standard)/referercessanclei

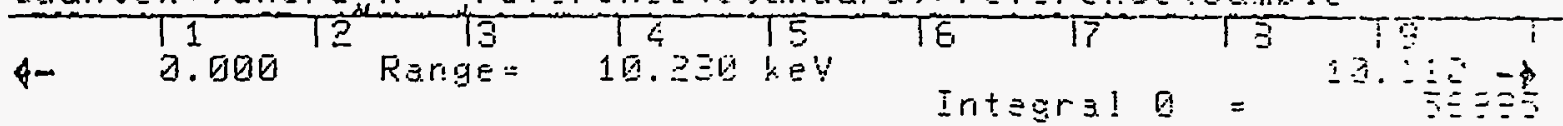


W. L. Boettinger

October 28, 1994

Page 10 of 15

WSRC-TR-94-0527

FIGURE 4

Photograph of Ingot from the Second Clean Melt (Mag. 1/3 X)

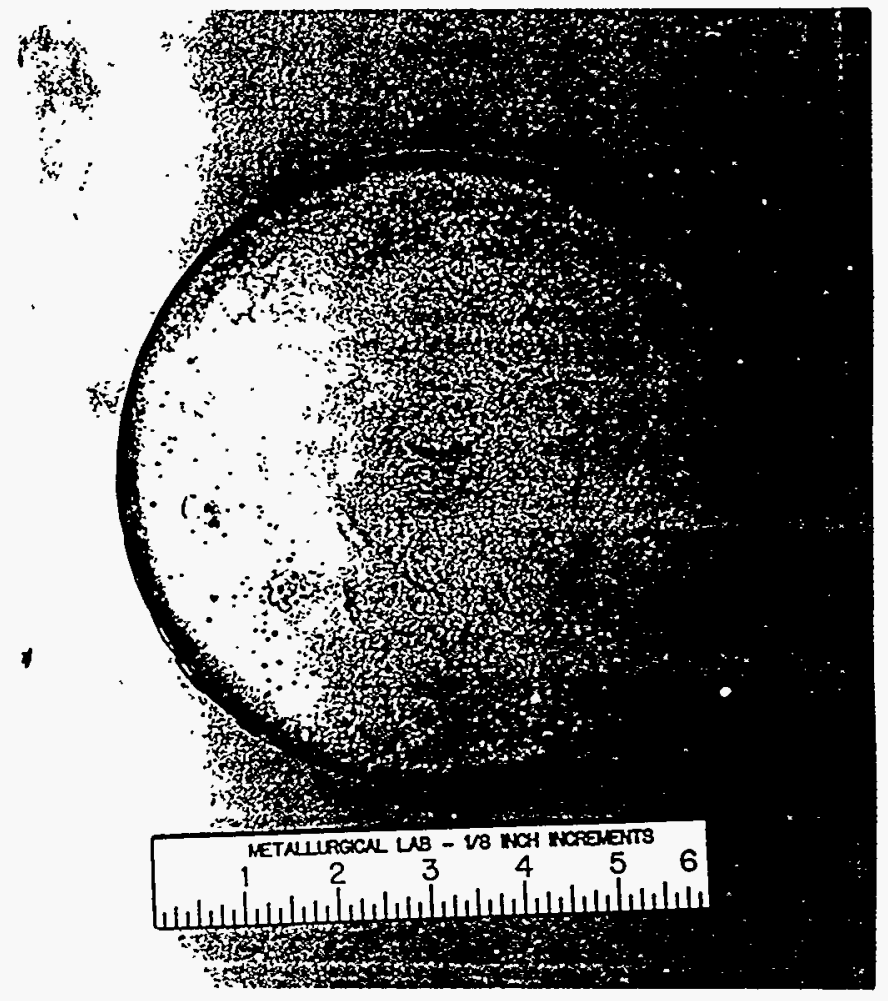


W. L. Boettinger

October 28, 1994

Page 11 of 15

WSRC-TR-94-0527

\section{FIGURE 5}

Photomicrograph Showing As-Cast Structure of Ingot from Second Clean Melt (Mag. 100 X)

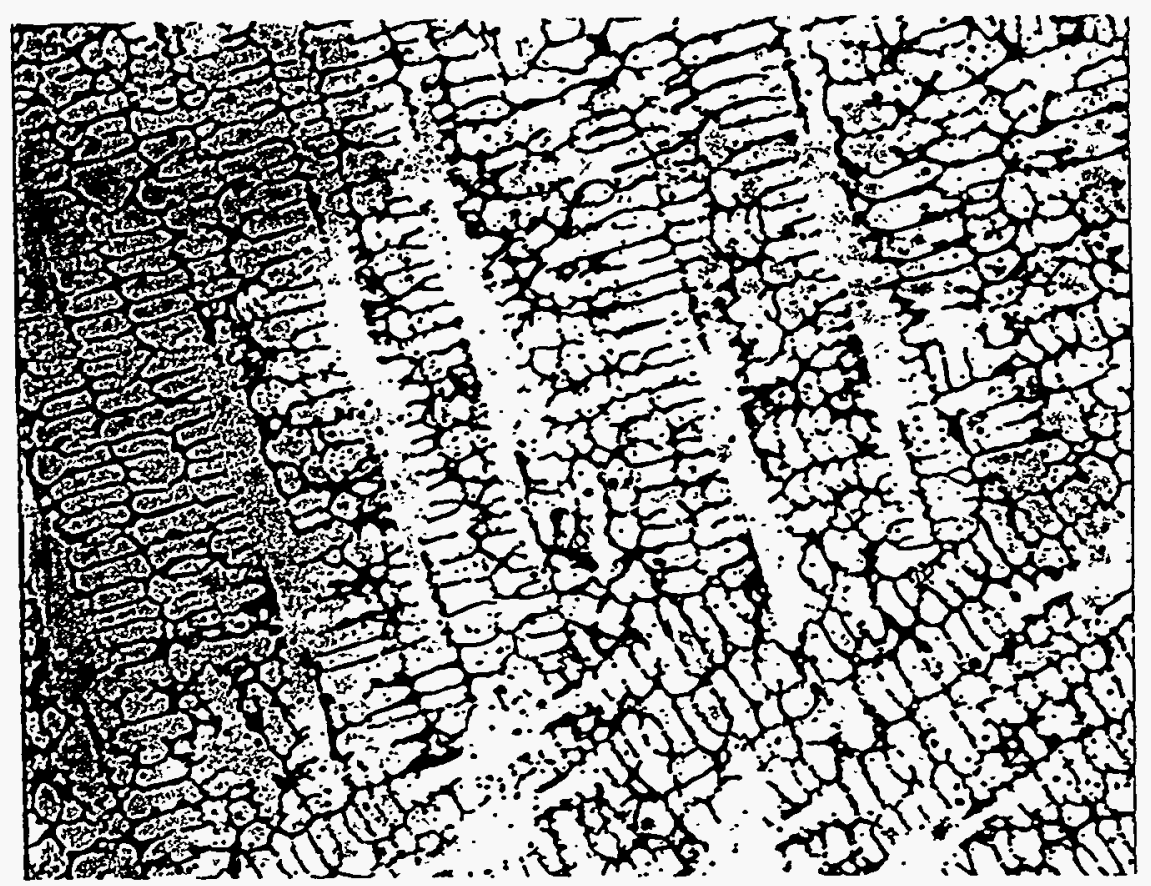


W. L. Boettinger

October 28, 1994

Page 12 of 15

WSRC-TR-94-0527

\section{FIGURE 6}

Photomicrograph Showing Directionally Solidified Microstructure of Ingot from the Third Clean Melt (Mag. 64 X)

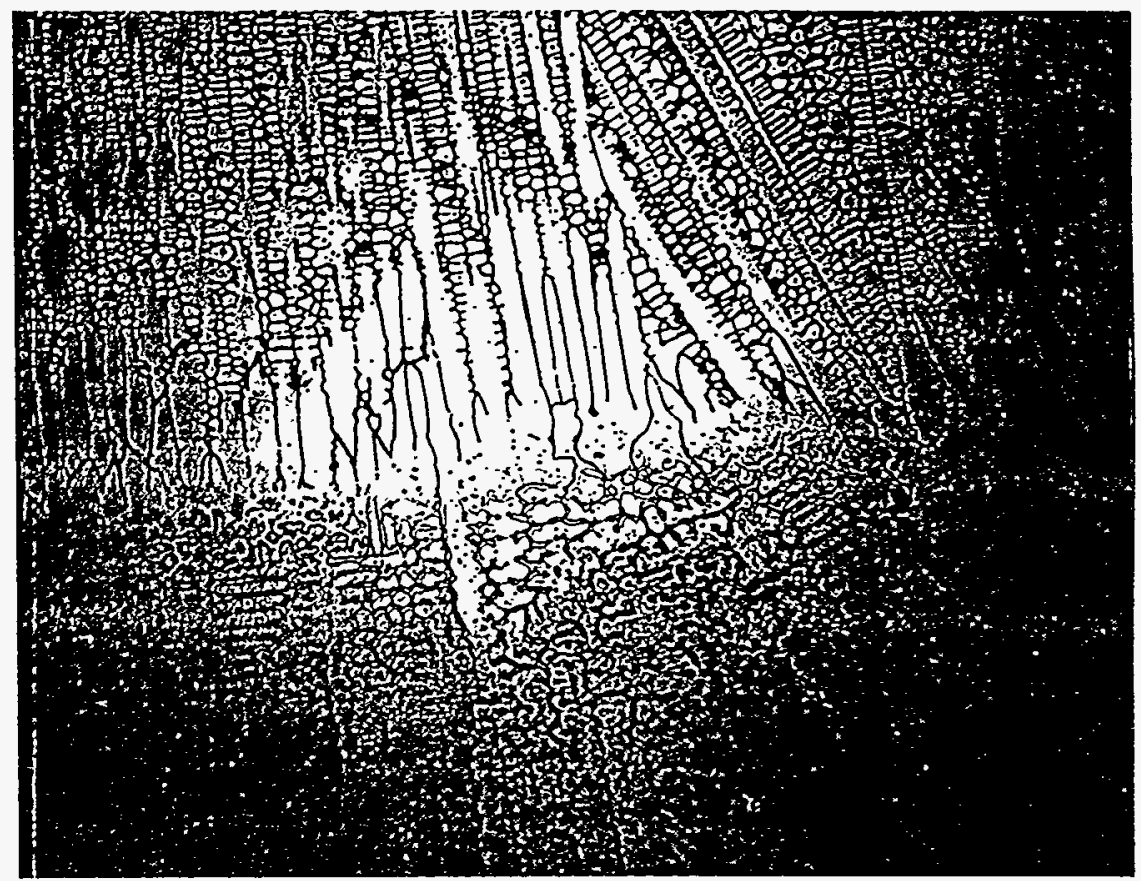


W. L. Boettinger

October 28, 1994

Page 13 of 15

WSRC-TR-94-0527

\section{FIGURE 7}

\section{Photomicrograph of Ingot from the Third Clean Melt in the As-Rolled Condition (Mag. $250 \mathrm{X}$ )}

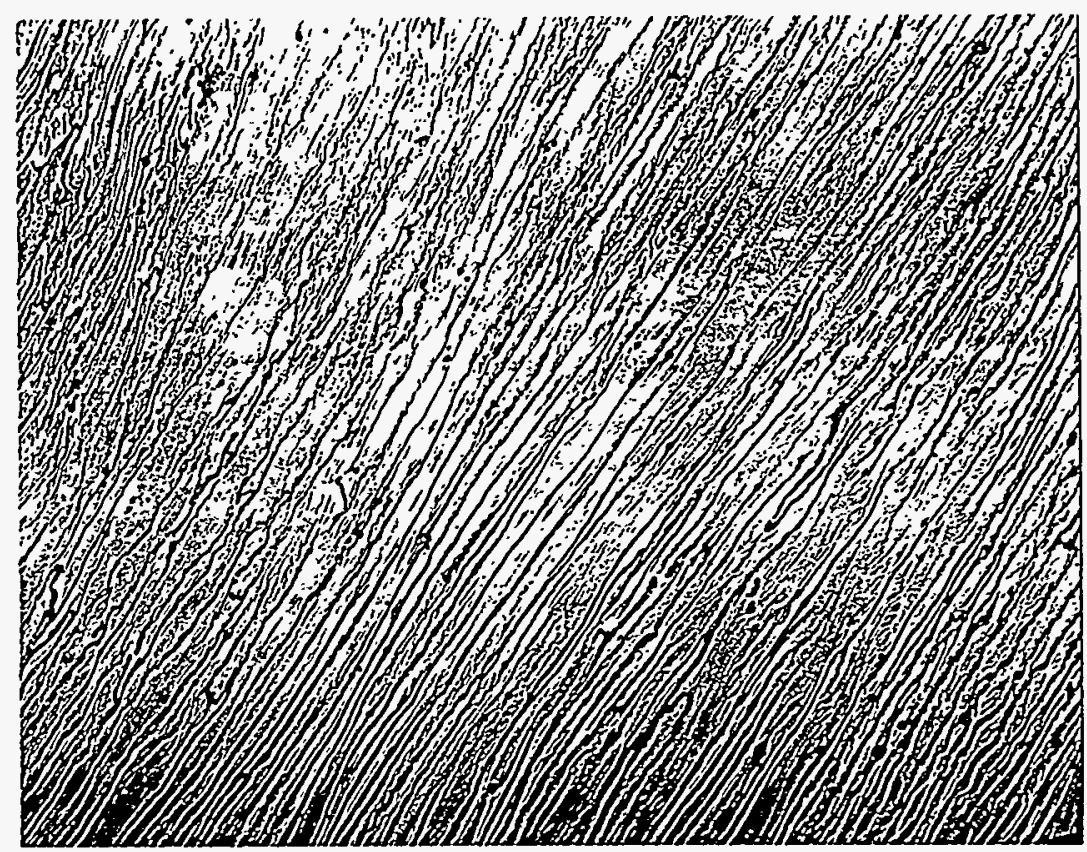


W. L. Boettinger

October 28, 1994

Page 14 of 15

WSRC-TR-94-0527

FIGURE 8

Photomicrograph of Ingot from the Third Clean Melt in the As-Rolled and Heat Treated Condition (Mag. 250 X)

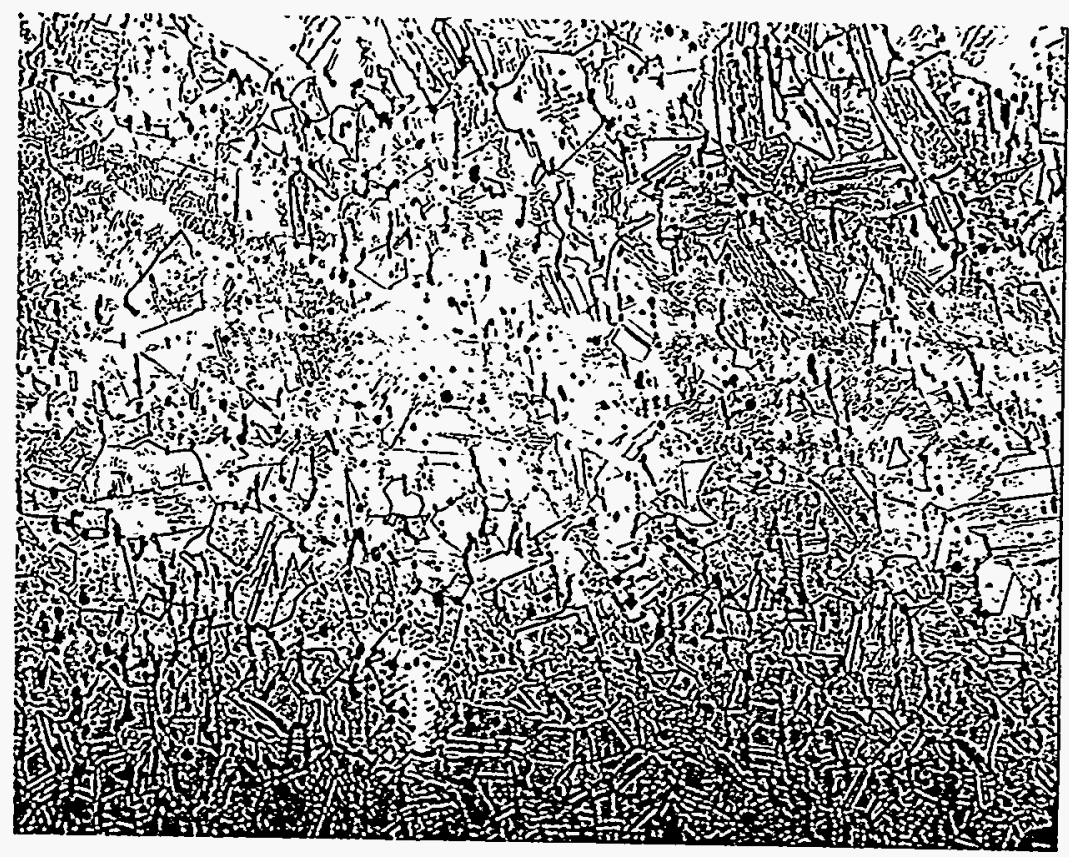


W. L. Boettinger

October 28, 1994

Page 15 of 15

WSRC-TR-94-0527

\section{FIGURE 9}

Photomicrograph of Ingot form the Second Contaminated Melt in the As-Cast Condition (Mag. 100 X)

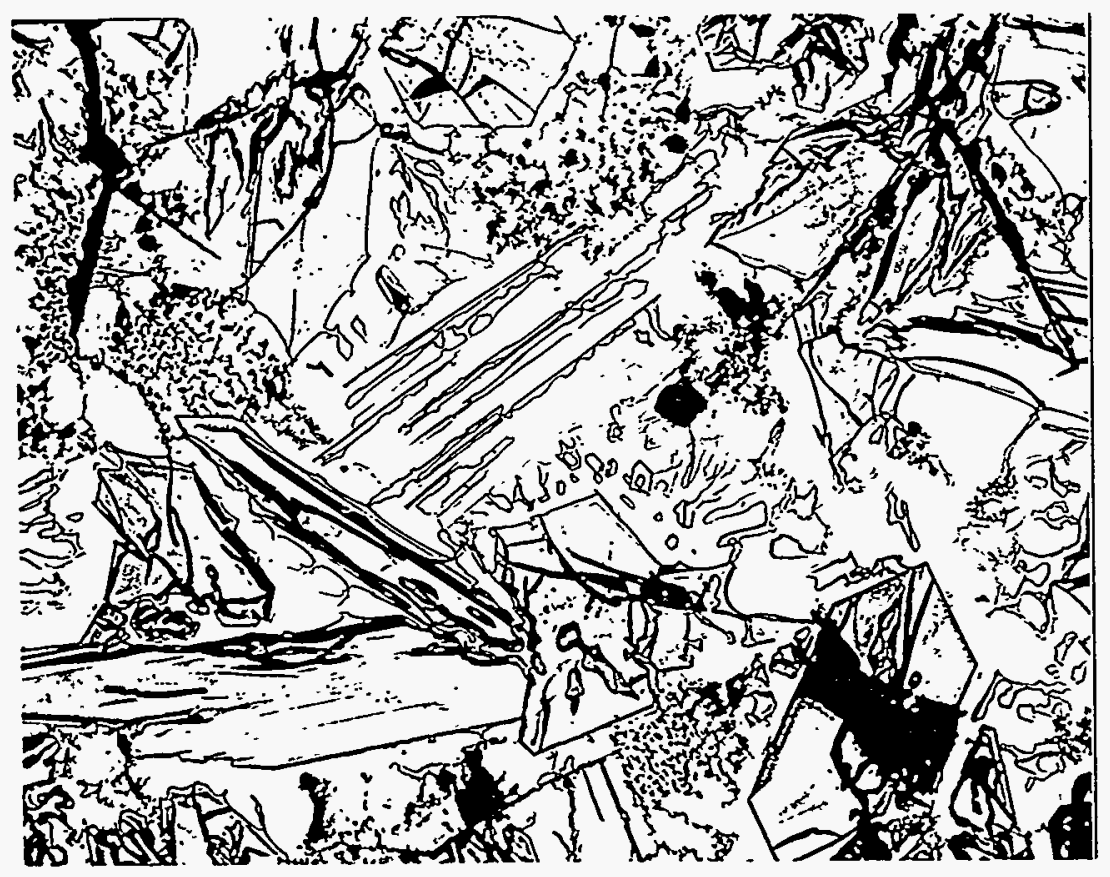

